\title{
Changes in antioxidant enzyme activities in Eichhornia crassipes (Pontederiaceae) and Pistia stratiotes (Araceae) under heavy metal stress
}

\author{
V.J. Odjegba ${ }^{1} \&$ I.O. Fasidi ${ }^{2}$ \\ 1 Department of Botany and Microbiology, University of Lagos, Akoka, Yaba, Lagos, Nigeria; odjesvic@yahoo.com. \\ Tel: $+234-8023323406$ \\ 2 Department of Botany and Microbiology, University of Ibadan, Ibadan, Nigeria.
}

Received 18-V-2006. Corrected 28-XI-2006. Accepted 07-V-2007.

\begin{abstract}
Whole plants of Eichhornia crassipes and Pistia stratiotes were exposed to various concentrations ( 0 , $0.1,0.3,0.5,1.0,3.0$ and $5.0 \mathrm{mM}$ ) of 8 heavy metals ( $\mathrm{Ag}, \mathrm{Cd}, \mathrm{Cr}, \mathrm{Cu}, \mathrm{Hg}, \mathrm{Ni}, \mathrm{Pb}$ and $\mathrm{Zn}$ ) hydroponically for 21 days. Spectrometric assays for the total activity of catalase, peroxidase, and superoxide dismutase in the leaves were studied. At the end of the experimental period, data referred to metal treated plants were compared to data of untreated ones (control). Heavy metals increased the activity of catalase, peroxidase and superoxide dismutase in both species and there was differential inducement among metals. Overall, $\mathrm{Zn}$ had the least inducement of antioxidant enzymes in both species while $\mathrm{Hg}$ had the highest inducement. The increase in antioxidant enzymes in relation to the control plants was more in E. crassipes than P. stratiotes. The results showed that E. crassipes tolerated higher metal concentrations in a greater number of metals than P. stratiotes. Rev. Biol. Trop. 55 (3-4): 815-823. Epub 2007 December, 28.
\end{abstract}

Key words: catalase, peroxidase, superoxide dismutase, Eichhornia crassipes, heavy metals, Pistia stratiotes, reactive oxygen species.

The production of reactive oxygen species (ROS), such as singlet oxygen $\left({ }^{1} \mathrm{O}_{2}\right)$, superoxide radical $\left(\mathrm{O}_{2}^{-}\right)$and hydrogen peroxide $\left(\mathrm{H}_{2} \mathrm{O}_{2}\right)$, intrinsically accompanies photosynthesis (Mano et al. 2002). In chloroplasts, singlet oxygen $\left({ }^{1} \mathrm{O}_{2}\right)$ is formed by energy transfer to oxygen $\left(\mathrm{O}_{2}\right)$ from triplet excited state chlorophyll, and superoxide radical $\left(\mathrm{O}_{2}^{-}\right)$is produced by photoreduction of oxygen at photosystem I (PSI) and photosystem II (PSII) (IturbeOrmaetxe et al. 1998). Hydrogen peroxide $\left(\mathrm{H}_{2} \mathrm{O}_{2}\right)$ is produced by the glycollate oxidase reaction in the process of photorespiration (Foyer et al. 1994).

Most cellular compartments have the potential to become a source of ROS. Environmental stress conditions that limit $\mathrm{CO}_{2}$ fixation, such as drought and salt stress, ozone and high or low temperatures, reduce the $\mathrm{NADP}^{+}$ regeneration by the Calvin cycle, consequently, the photosynthetic electron transport chain is over-reduced, forming superoxide radicals and singlet oxygen $\left({ }^{1} \mathrm{O}_{2}\right)$ in the chloroplasts (Krause 1994). To prevent over-reduction of the electron transport chain under conditions that limit $\mathrm{CO}_{2}$ fixation, plants have evolved the photorespiratory pathway to regenerate $\mathrm{NADP}^{+}$ (Kozaki and Takeba 1996). As part of the photorespiratory pathway, $\mathrm{H}_{2} \mathrm{O}_{2}$ is formed in the peroxisomes, where it can also be produced during the catabolism of lipids as a by-product of $\beta$-oxidation of fatty acids (Somerville et al. 2000). When growth and other energy requiring processes in plants are reduced as a result of stress, the electron transport chain in the mitochondria may become over-reduced, favouring the generation of superoxide radical (Purvis 1997). The detoxification reactions catalysed 
by cytochrome $\mathrm{P}_{450}$ in the cytoplasm and the endoplasmic reticulum also leads to the formation of ROS. During these reactions, electron leakage to oxygen and the decomposition of the intermediate oxygenate of cytochrome $\mathrm{P}_{450}$ can form $\mathrm{O}_{2}^{-}$(Urban et al. 1997).

Heavy metals are defined as metals with a density higher than $5 \mathrm{gcm}^{-3}$. Based on their solubility under physiological conditions, 17 heavy metals may be available for living cells and of importance for organism and ecosystems (Weast 1984). Among these metals, Fe, Mo and $\mathrm{Mn}$ are important as micronutrients, while $\mathrm{Zn}$, $\mathrm{Ni}, \mathrm{Cu}, \mathrm{V}, \mathrm{Co}, \mathrm{W}$, and $\mathrm{Cr}$ are toxic elements with high or low importance as trace elements. On the other hand, $\mathrm{As}, \mathrm{Hg}, \mathrm{Ag}, \mathrm{Sb}, \mathrm{Cd}, \mathrm{Pb}$, and $\mathrm{U}$ have no known function as nutrients and are toxic to plants (Nies 1999).

Toxic levels of some heavy metals appear as a result of environmental pollution due to the removal technology of mining, heavy automobile traffic, smelting, manufacturing, and agricultural wastes in natural and agricultural areas (Oncel et al. 2000). Since these metals are not readily degraded by microbial activities, they tend to pollute the environment thereby constituting environmental stress.

In plants, damage arising from a wide range of biotic and abiotic environmental stresses appears to be directly or indirectly caused by reactive oxygen species. They are highly destructive to the cellular components of proteins, membrane lipids and nucleic acids (Matsumura et al. 2002). As reactive oxygen species are produced in significant quantities in sub-cellular compartments or organelles, each organelle has potential targets for oxidative stress as well as mechanisms for eliminating the noxious oxyradicals. The control of oxidant levels is achieved by antioxidant systems. Under non-perturbed conditions, steady state equilibrium probably exists between reactive oxygen species formation and their scavenging by means of enzymes known as antioxidants. Among the antioxidants, catalase (CAT), peroxidase (PRX), and superoxide dismutase (SOD) are reputed to be the most important (De Biasi et al. 2003). Since reactive oxygen species are potentially destructive chemical species, it is conceivable that the cellular balance between reactive oxygen species formation and consumption has to be kept under tight control. Hence, an increase in the level and/or activity of antioxidants is often believed to indirectly reflect on increase in reactive oxygen species formation (Foyer et al. 1997).

In the past, E. crassipes and P. stratiotes have been implicated in the phytoremediation of waters polluted with low levels of heavy metals (Muramoto and Oki 1983, Qian et al. 1999, Odjegba and Fasidi 2004). But this metal accumulation potential possessed by these plants is not without some pronounced effects on the plants. It has been reported that responses such as root growth and development, leaf expansion and relative growth rate of $P$. stratiotes was significantly hindered when subjected to heavy metal stress (Odjegba and Fasidi 2004). The present study was conducted to determine whether part of the differences in stress tolerance between E. crassipes and P. stratiotes could be explained by differences in reactive oxygen metabolism. Our hypotheses were:

a. Nonlethal concentrations of heavy metals would cause increased oxidative stress and therefore induce defence systems against ROS and that the effects of the metals would be different.

b. Species with overall higher levels of antioxidant enzyme activity would comparatively tolerate heavy metal stress more than the other species.

\section{MATERIALS AND METHODS}

E. crassipes and P. stratiotes were collected from Oba dam, University of Ibadan, Oyo State, Nigeria. Plants were washed thoroughly under a running tap water, propagated for four weeks hydroponically and subjected to heavy metal treatments as described earlier by Odjegba and Fasidi (2004), using Hoagland's solution as modified by Punshon and Dickinson (1997). 
Enzyme assays: plants were harvested at the end of the experiment period and thoroughly washed under a running tap water. The leaves were collected for the preparation of extracts used for the enzyme assays. Crude extract was prepared by grinding $1 \mathrm{~g}$ of leaves in $10 \mathrm{ml}$ distilled water using ceramic mortal and pestle. Filtration was made using labsman no 1 filter paper and the filtrate utilized for enzyme analyses (De Biasi et al. 2003).

Catalase activity was measured according to the method of Matsumura et al. (2002) in a reaction mixture containing $1 \mathrm{ml}$ of $5 \mathrm{mM}$ potassium phosphate ( $\mathrm{pH} 7.0), 1 \mathrm{ml}$ of $45 \mathrm{mM}$ $\mathrm{H}_{2} \mathrm{O}_{2}$ and $1 \mathrm{ml}$ of the crude extract. The activity was determined by the decrease of absorbance at $240 \mathrm{~nm}$ due to $\mathrm{H}_{2} \mathrm{O}_{2}$ consumption using Corning 258 spectrophotometer. One unit was defined as $1 \mathrm{mM}$ of $\mathrm{H}_{2} \mathrm{O}_{2}$ decomposed per minute and the activity referred to milligrams of protein. Protein was determined in extract according to the method described by Bradford (1976).

Peroxidase activity was determined according to the method of Chanda and Singh (1997). The reaction mixture contained $1 \mathrm{ml}$ of the leaf extract, $1 \mathrm{ml}$ of $1 \mathrm{mM} \mathrm{H} \mathrm{O}_{2}, 1 \mathrm{ml}$ of $4 \mathrm{mM}$ guaiacol and $1 \mathrm{ml} 8 \mathrm{mM}$ potassium phosphate buffer ( $\mathrm{pH}$ 6.5). The change in absorbance at $470 \mathrm{~nm}$ due to the oxidation of guaiacol to form tetraguaiacol in the presence of $\mathrm{H}_{2} \mathrm{O}_{2}$ was measured. The Peroxidase activity was expressed as the rate of change of optical density (OD) per minute.

Superoxide dismutase activity was measured as described by Calatayud et al. (2002). The reaction mixture contained $1 \mathrm{ml}$ each of $50 \mathrm{mM}$ potassium phosphate buffer $(\mathrm{pH} 7.8)$, $10 \mathrm{mM}$ methionine, $57 \mu \mathrm{M}$ nitroblue tetrazolium (NBT), $1.0 \mu \mathrm{M}$ riboflavin, $0.025 \%(\mathrm{v} / \mathrm{v})$ Triton X-100 and crude extract. The mixture was thoroughly shaken and illuminated for 5 min with 60 Watt electric bulb placed $20 \mathrm{~cm}$ away. Absorbance was recorded at $560 \mathrm{~nm}$ after the illumination period. In this assay, 1 unit of SOD was defined as the amount of enzyme necessary to produce a $50 \%$ inhibition of the NBT photoreduction.
Statistical analysis: data analyses were performed using SAS version 6.0. Variance analysis (ANOVA) was performed on experimental data. For mean separations, Duncan's multiple range test (DMRT) was used at $\mathrm{p} \leq 0.05$.

\section{RESULTS}

Generally, heavy metals increased the activities of the antioxidant enzymes investigated, and the increase was proportional to metal concentration. However, there was a differential level of inducement among metals and this had a direct relationship with the tolerance of the metal by the plant species. Both species could not tolerate high concentration of $\mathrm{Hg}$, as concentrations $\geq 0.5 \mathrm{mM}$ of these metals were lethal to both species. Yet, low concentrations of this metal induced antioxidant enzyme activities to significant $(\mathrm{p} \leq 0.05)$ high level compared to other metals.

The control E. crassipes had $0.38 \pm 0.02$ $\mu$ molmg ${ }^{-1}$ protein of catalase activity, while 0.3 $\mathrm{mM}$ of $\mathrm{Hg}, \mathrm{Ni}, \mathrm{Cr}$ and $\mathrm{Zn}$ induced $0.84 \pm 0.01$, $0.68 \pm 0.02,0.46 \pm 0.01$ and $0.42 \pm 0.02 \mu$ molmg $^{-1}$ protein of catalase activity respectively (Fig. 1). Similarly, $0.3 \mathrm{mM}$ of $\mathrm{Hg}$ and $\mathrm{Ni}$ induced $0.82 \pm 0.02$ and $0.72 \pm 0.01 \mu \mathrm{molmg}^{-1}$ protein respectively in $P$. stratiotes, these values were significantly $(\mathrm{p} \leq 0.05)$ higher than $0.62 \pm 0.01$, $0.69 \pm 0.02,0.50 \pm 0.01$ and $0.47 \pm 0.01 \mu \mathrm{molmg}^{-1}$ protein of catalase activity recorded for $0.3 \mathrm{mM}$ $\mathrm{Ag}, \mathrm{Cd}, \mathrm{Cr}$ and $\mathrm{Zn}$ respectively (Fig. 2).

Peroxidase activity in E. crassipes and $P$. stratiotes as affected by heavy metals are as shown in Fig. 3 and 4 respectively. The control E. crassipes and P. stratiotes had $0.010 \pm 0.001$ and $0.015 \pm 0.001$ units of activity respectively. These values were significantly $(p \leq 0.05)$ lower than the values recorded for $\geq 0.3 \mathrm{mM}$ treatment concentrations for all the metals investigated.

Fig. 5 and 6 shows the effects of heavy metals on the superoxide dismutase activity in E. crassipes and P. stratiotes respectively. There was a significant $(\mathrm{p} \leq 0.05)$ increase in SOD activity when metals were supplied at $\geq 0.3 \mathrm{mM}$. 


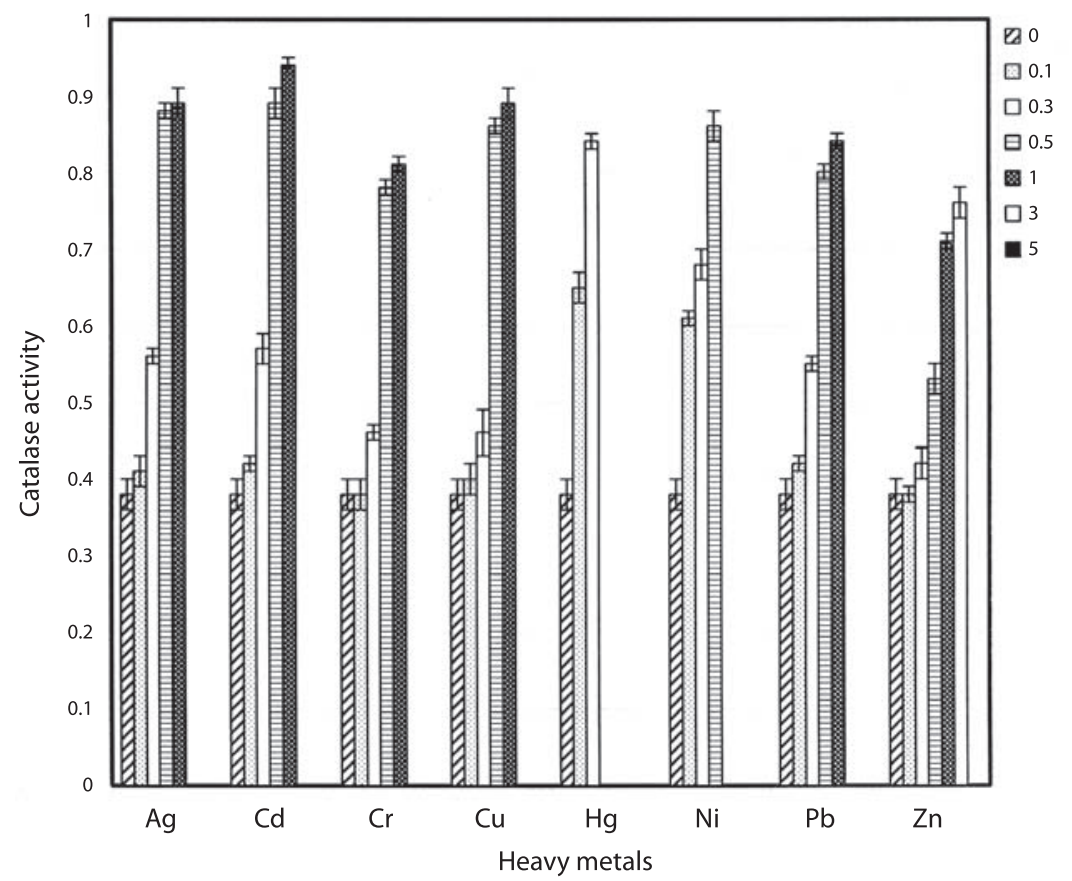

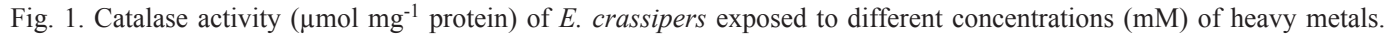
Means and standard errors are shown, $n=3$.

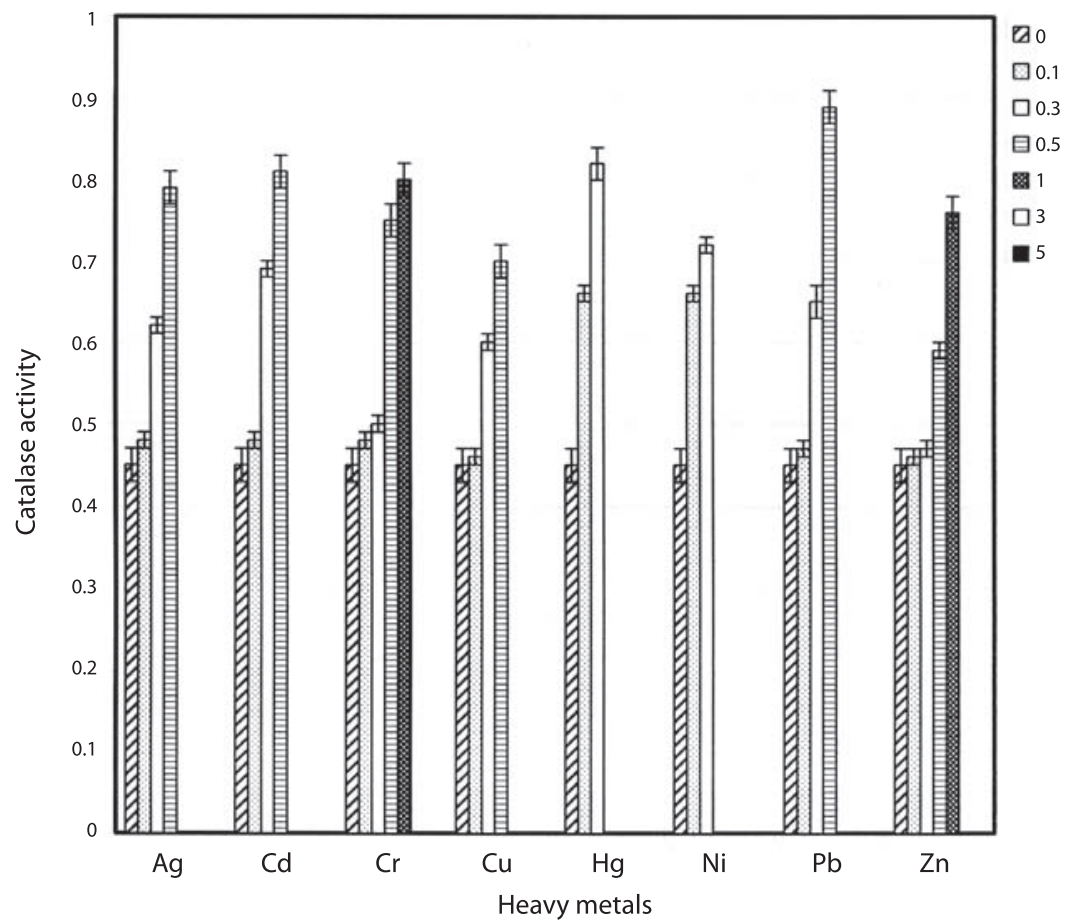

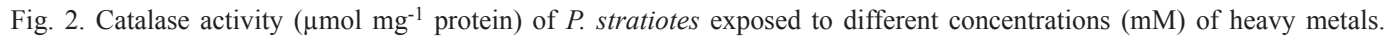
Means and standard errors are shown, $n=3$. 


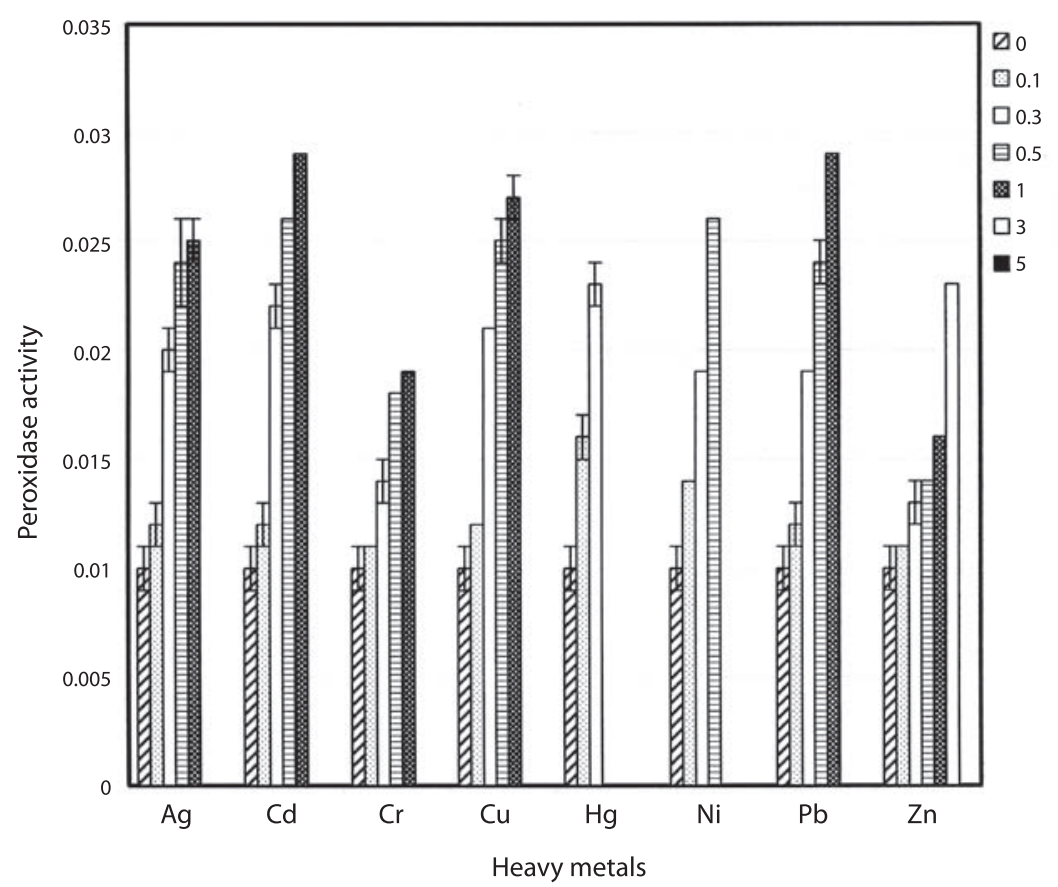

Fig. 3. Peroxidase activity $\left(\Delta_{470} \mathrm{~min}^{-1} \mathrm{~g}^{-1}\right.$ fresh weight) of E. crassipers treated with different concentrations (mM) of heavy metals. Means and standard errors are shown, $n=3$.

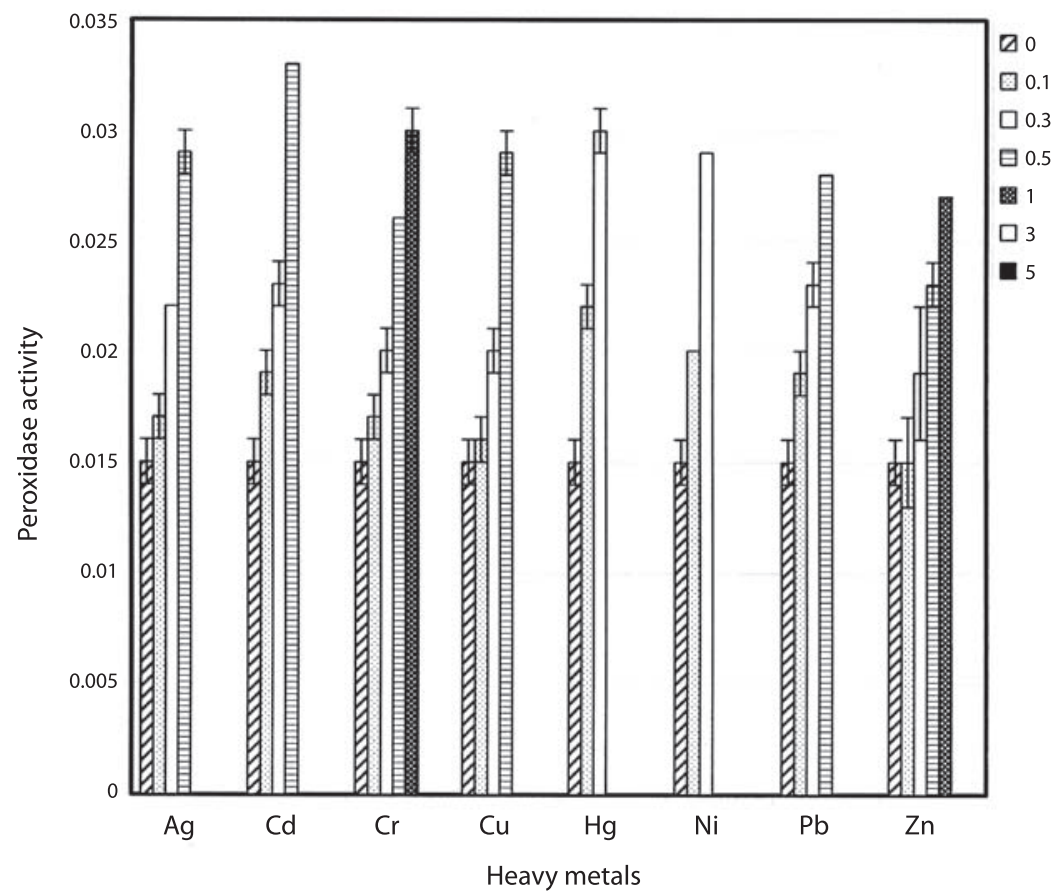

Fig. 4. Peroxidase activity $\left(\Delta_{470} \mathrm{~min}^{-1} \mathrm{~g}^{-1}\right.$ fresh weight) of $P$. stratiotes treated with different concentrations (mM) of heavy metals. Means and standard errors are shown, $n=3$. 


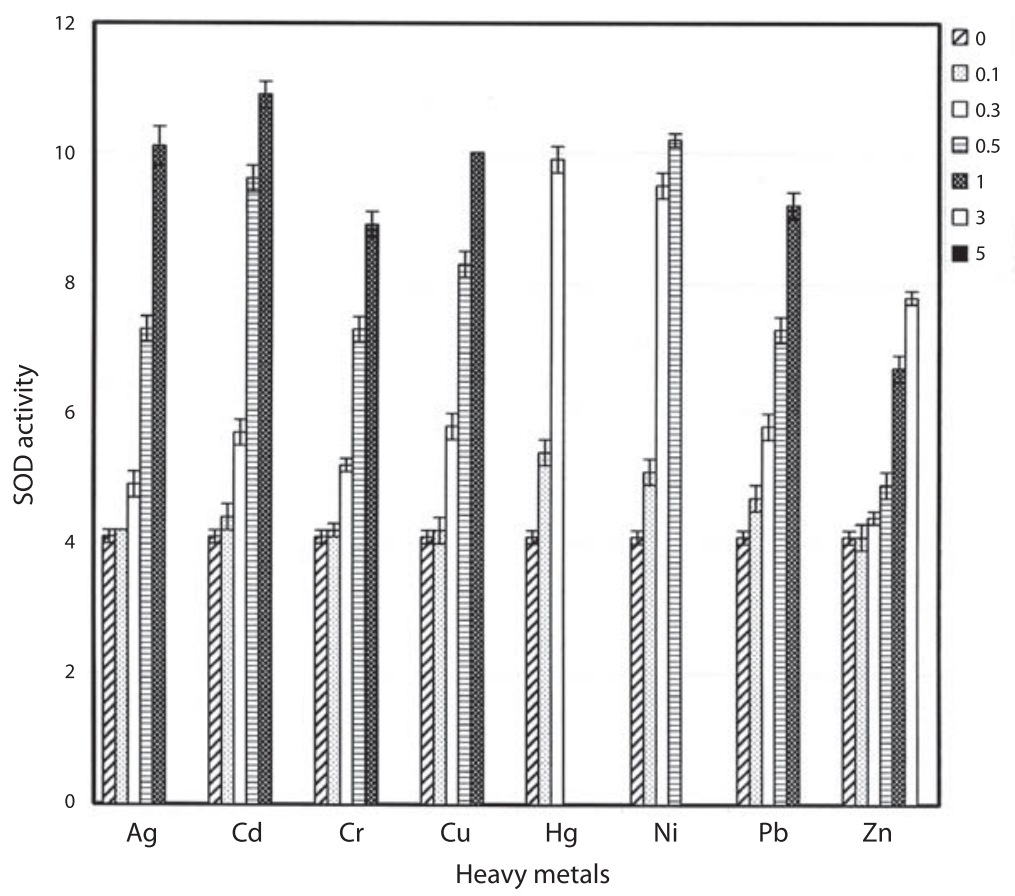

Fig. 5. Superoxide dismutase activity (units $\mathrm{mg}^{-1}$ protein) of E. crassipers exposed to various concentrations (mM) of heavy metals. Means and standard errors are shown, $n=3$.

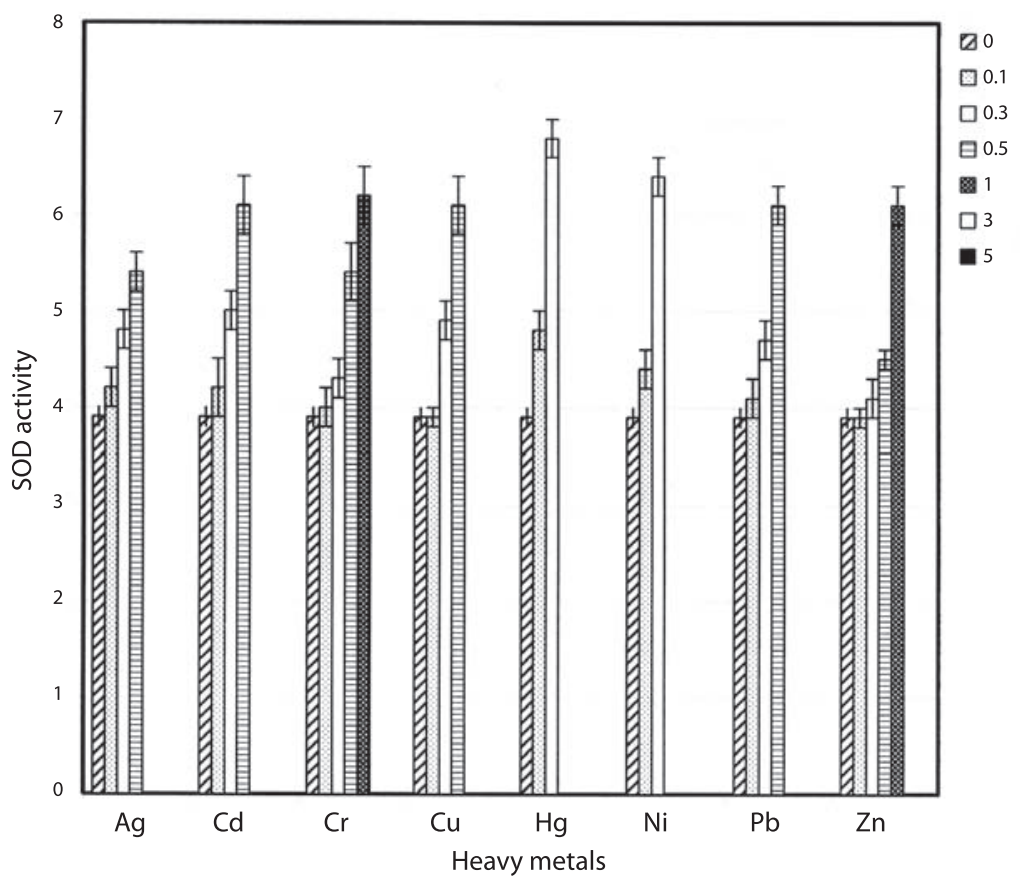

Fig. 6. Superoxide dismutase activity (units $\mathrm{mg}^{-1}$ protein) of $P$. stratiotes exposed to various concentrations (mM) of heavy metals. Means and standard errors are shown, $n=3$. 
Overall, $\mathrm{Zn}$ had the least inducement of antioxidant enzymes in both species while $\mathrm{Hg}$ had the highest inducement. This reflects a direct relationship with the tolerance levels of these metals by these species. E. crassipes survived $3.0 \mathrm{mM} \mathrm{Zn}$ but $0.5 \mathrm{mM} \mathrm{Hg}$ was lethal. Similarly, P. stratiotes tolerated $1.0 \mathrm{mM}$ $\mathrm{Zn}$ but could not survive when exposed to 0.5 $\mathrm{mM} \mathrm{Hg}$.

\section{DISCUSSION}

The direct interaction of heavy metals with cellular components can initiate a variety of metabolic responses, finally leading to a shift in the development of the plant. In general, the stress point is defined as the metabolic state where the regulation of pathways towards the positive direction for plant fitness is at its limits (Elstner et al. 1988). For metal toxicity, this stress point is reached at the toxic threshold level of the metal in the tissue. Above this level, the physiological state of the cell will be irreversibly changed. This change is reflected by an increase in activity of certain enzymes defined as enzyme induction. Based on the chemical and physical properties of heavy metals, three different molecular mechanisms can be distinguished: (a) production of reactive oxygen species by autoxidation and Fenton reaction; (b) blocking of essential functional groups in biomolecules; (c) displacement of essential metal ions from biomolecules.

For a long time, reactive oxygen species have been regarded mainly as dangerous molecules, whose levels need to be kept as low as possible. This opinion is now changing, because it has been realized that reactive oxygen species play important roles in plant's defence system against pathogen (Bowell et al. 2002), mark certain developmental stages such as tracheary element formation, lignification and other cross-linking processes in the cell wall (Teichmann 2001, Fath et al. 2002) and act as intermediate signaling molecules to regulate the expression of genes (Neill et al. 2002, Vranova et al. 2002). Because of these multiple functions of reactive oxygen species, it is necessary for cells to control the level these molecules tightly, but not to completely eliminate them. This was found to be true in this study, as the activity of antioxidant enzymes also occurred in the control plants which was an indication of the presence of reactive oxygen species in these plants' cells.

Our data supported the two hypotheses:

a. Nonlethal concentrations of heavy metals would cause increased oxidative stress and therefore induce defence systems against ROS and that the effects of the metals would be different.

b. Species with overall higher levels of antioxidant enzyme activity would comparatively tolerate heavy metal stress more than the other species.

The results presented in this study showed that heavy metals increased the activity of catalase, peroxidase and superoxide dismutase in both species and there was differential inducement among metals. It is possible that heavy metal stress reduce the capacity of the plants to assimilate carbon, this would trigger an increase in photosynthetic electron flux to molecular oxygen, resulting in the increased production of superoxide, hydrogen peroxide, and hydroxyl radical. Since these reactive oxygen species are damaging to lipids, proteins and pigments, they are rapidly scavenged by antioxidant enzymes. There are evidences that increased levels of these scavenging enzymes may play a role in limiting the degree of photodamage to plants (Hodges et al. 1997, Collen and Davison 1999, Rao and Sresty 2000, Schutzendubel et al. 2001). The increase in antioxidant enzymes in relation to the control plants was more in E. crassipes than $P$. stratiotes. The results showed that E. crassipes tolerated higher metal concentrations in a greater number of metals than $P$. stratiotes, and this supported the second hypothesis.

The authors concluded that exposure of plants to heavy metals provoke pronounced 
responses of antioxidative systems which protects the plants to some extent against oxidative damage, but the direction of response was dependent on the plant species, the metal used for the treatment and the intensity of the stress.

\section{RESUMEN}

Plantas completas de Eichhornia crassipes y Pistia stratiotes fueron expuestas a varias concentraciones $(0,0.1$, 0.3, 0.5, 1.0, 3.0 and $5.0 \mathrm{mM})$ de metales pesados $(\mathrm{Ag}, \mathrm{Cd}$, $\mathrm{Cr}, \mathrm{Cu}, \mathrm{Hg}, \mathrm{Ni}, \mathrm{Pb}$ and $\mathrm{Zn}$ ) utilizando hidroponía, por 21 días. Se realizaron análisis espectrométricos en las hojas para determinar la actividad total de la catalasa, peroxidasa y dismutasa superóxida. Al final del periodo experimental, se comparó con plantas no tratadas (control). Los metales pesados incrementan la actividad de la catalasa, peroxidasa y la dismutasa superóxida para ambas especies y hay diferencias entre los metales. El Zn produce el menor estímulo para enzimas antioxidantes en ambas especies; $\mathrm{Hg}$ produce el mayor estímulo. El incremento de las enzimas antioxidantes en relación con las plantas control fue mayor en $E$. crassipes que $P$. stratiotes. E. crassipes tolera altas concentraciones de metal en un gran número de ellos, mientras que la tolerancia en $P$. stratiotes es menor.

Palabras clave: catalasa, peroxidasa, dismutasa superoxida, Eichhornia crassipes, metales pesados, Pistia stratiotes, especies reactivas al oxígeno.

\section{REFERENCES}

Bolwell, G.P., L.V. Bindschedler, K.A. Blee, V.S. Butt, D.R. Davies, S.L. Gardner, C. Gerrish \& F. Minibayeva. 2002. The apoplastic oxidative burst in response to biotic stress in plants: a three-component system. J. Exp. Bot. 53: 1367-1376.

Bradford, M.M. 1976. A rapid and sensitive method for the quantification of microgram quantities of protein, utilizing the principle of protein-dye binding. Anal. Biochem. 72: 248-254.

Calatayud, A., J.W. Ramirez, D.J. Iglesias \& E. Barreno. 2002. Effects of ozone on photosynthetic $\mathrm{CO}_{2}$ exchange, chlorophyll $a$ fluorescence and antioxidant system in lettuce leaves. Physiol. Plant. 116: 308-316.

Chanda, S.V. \& Y.D. Singh. 1997. Changes in peroxidase and IAA oxidase activities during wheat grain development. Plant Physiol. Biochem. 35: 245-250.
Collen, J. \& I.R. Davison. 1999. Stress tolerance and reactive oxygen metabolism in the intertidal red seaweeds Mastocarpus stellatus and Chondrus crispus. Plant Cell Environ. 22: 1143-1151.

De Biasi, M.G., S. Astolfi, A. Acampora, S. Zuchi, V. Fonzo, E. Satangelo, R. Caccia, M. Badiani \& G.P. Soressi. 2003. A $\mathrm{H}_{2} \mathrm{O}_{2}$-forming peroxidase rather than a $\mathrm{NAD}(\mathrm{P}) \mathrm{H}$-dependent $\mathrm{O}_{2}^{-}$synthase may be the major player in cell death responses controlled by the pto-Fen complex following fenthion treatment. Funct. Plant Biol. 30: 409-417.

Elstner, E.F., G.A. Wagner \& W. Schutz. 1988. Activated oxygen in green plants in relation to stress situations. Curr. Topics Plant Biochem. Physiol. 7: 159-187.

Fath, A., P. Bethke, V. Belligni \& R. Jones. 2002. Active oxygen and cell death in cereal aleurone cells. J. Exp. Bot. 53: 1273-1282.

Foyer, C.H., P. Descourvieres \& K.J. Kunert. 1994. Protection against oxygen radicals: an important defence mechanism studied in transgenic plants. Plant Cell Environ. 17: 507-523.

Foyer, C.H., H. Lopez-Delgado, J.F. Dat \& I.M. Scott. 1997. Hydrogen peroxide and glutathione-associated mechanisms of acclimatory stress tolerance and signaling. Physiol. Plant. 100: 241-254.

Hodges, D.M., C.J. Andrews, D.A. Johnson \& R.I. Hamilton. 1997. Antioxidant enzyme responses to chilling stress in differentially sensitive inbred maize lines. J. Exp. Bot. 48: 1105-1113.

Iturbe-Ormaetxe, I., P.R. Escuredo, C. Arrese-Igor \& M. Becana. 1998. Oxidative damage in pea plants exposed to water deficit or paraquat. Plant Physiol. 116: $174-181$.

Kozaki, A. \& G. Takeba. 1996. Photorespiration protects C3 plants from photooxidation. Nature 384: 557-560.

Krause, G.H. 1994. The role of oxygen in photoinhibition of photosynthesis, p. 43-76. In C.H. Foyer \& P.M. Mullineaux (eds.) Causes of photooxidative stress and amelioration of defense systems in plants. Boca Raton, Florida, USA.

Matsumura, T., N. Tabayashi, Y. Kamagata, C. Souma \& H. Saruyama. 2002. Wheat catalase expressed in transgenic rice can improve tolerance against low temperature stress. Physiol. Plant. 116: 317-327.

Mano, J., Y. Torii, S. Hayashi, K. Takimoto, K. Matsui, K. Nakamura, D. Inze, E. Babiychuk, S. Kushmir \& 
K. Asada. 2002. The NADPH: Quinone oxidoreductase P1- $\zeta$-crystallin in Arabidopsis catalyzes the $\alpha$, $\beta$-Hydrogenation of 2-alkenals: Detoxication of the lipid peroxide-derived reactive aldehydes. Plant Cell Physiol. 43: 1445-1455.

Muramoto, S. \& Y. Oki. 1983. Removal of some heavy metals from polluted water by water hyacinth (Eichhornia crassipes). Bull. Environ. Contam. Toxicol. 30: 170-177.

Neill, S.J., R. Desikan, A. Clarke, R.D. Hurst \& J.T. Hankock. 2002. Hydrogen peroxide and nitric oxide as signaling molecules in plants. J. Exp. Bot. 53: 1237-1247.

Neis, D.H. 1999. Microbial heavy-metal resistance. Applied Microbiol. Biotech. 51: 730-750.

Odjegba, V.J. \& I.O. Fasidi 2004. Accumulation of trace elements by Pistia stratiotes: Implications for phytoremediation. Ecotoxicol. 13: 637-646.

Oncel, I., Y. Kele \& A.S. Ustun. 2000. Interactive effects of temperature and heavy metal stress on the growth and some biochemical compounds in wheat seedlings. Environ. Poll. 107: 315-320.

Punshon, T. \& N.M. Dickinson. 1997. Acclimation of Salix to metal stress. New Phytol. 137: 303-314.

Purvis, A.C. 1997. Role of the alternative oxidase in limiting superoxide production by plant mitochondria. Physiol. Plant. 100: 165-170.

Qian, J.H., A. Zayed, Y.L. Zhu, M. Yu, \& N. Terry. 1999. Phytoaccumulation of trace elements by wetland plants: III. Uptake and accumulation of ten trace elements by twelve plant species. J. Environ. Qual. 28: $1448-1455$
Rao, K.V.M. \& T.V.S. Sresty. 2000. Antioxidative parameters in the seedlings of peageonpea (Cajanus cajan) in response to $\mathrm{Zn}$ and $\mathrm{Ni}$ stresses. Plant Sci. 157: 113-128.

SAS Institute. 1989. SAS procedures guide. Version 6. SAS Institute, Cary, North Carolina, USA.

Schutzendubel, A., P. Schwanz, T. Teichmann, K. Gross, R. Langenfeld-Heyser, D.L. Godbold \& A. Polle. 2001. Cadmium-induced changes in antioxidative systems, H2O 2 content and differentiation in pine (Pinus sylvestris) roots. Plant Physiol. 127: 887-892.

Somerville, C., J. Browse, J.G. Jaworski \& J.B. Ohlrogge. 2000. Lipids, p. 456-527. In B.B. Buchanan, W. Gruissem \& R.L. Jones (eds.). Biochemistry and molecular biology of plants. American Society of Plant Physiologists. Rockville, New Jersey, USA.

Teichmann, T. 2001. The biology of wood formation: scientific challenges and biotechnological perspective. Recent Res. Dev. Plant Physiol. 2: 269-284.

Urban, P., C. Mignotte, M. Kazmaier, F. Delorme \& D. Pompon. 1997. Cloning, yeast expression and characterization of the coupling of two distantly related Arabidopsis thaliana NADPH-cytochrome $\mathrm{P}_{450}$ reductases withP ${ }_{450}$ CYP73A5. J. Biol. Chem. 272: 19176-19186.

Vranova, E., D. Inze \& F. van Breusegem. 2002. Signal transduction during oxidative stress. J. Exp. Bot. 53: 1227-1236.

Weast, R.C. 1984. CRC Handbook of chemistry and physics, $64^{\text {th }}$ edition. Boca Raton, Florida, USA. 
